\title{
Polarizing Mexico
}

Joseph Heinzman, (jheinzman@internationalcollege.edu), Hodges University

Tamara F. Darnell, (Tamara_Darnell@internationalcollege.edu), MBA Student, Hodges University

\begin{abstract}
Mexico has been a third-world country for centuries. Through its historical path of turbulent governments, Mexico was continuously left in a worse economic condition than where it was in each previous regime. (Suchlicki, 1996) When NAFTA was signed, the hopes were to unite and increase trade between Canada, the United States and Mexico. It was also believed that NAFTA would solve all of Mexico's social, political and economic problems, demonstrating how free trade could aid in developing a nation such as Mexico. (Smith \& Lindlad, 2003) However, not all of Mexico was accepting NAFTA with open-arms. After the signing, there were hostile movements in Mexico (Suchlicki, 1996), attempted renegotiations of NAFTA ("Mexico Rejects," 2004) and a requirement for a delay in lifting some agricultural import barriers (Hall, Schwarf, and Root, 2006). While NAFTA is not a panacea for all of Mexico's economic woes, it is the path to a stronger Mexico in the future. The greatest obstacle to free trade lies within Mexico's divided culture and internal derision.
\end{abstract}

\section{HISTORY}

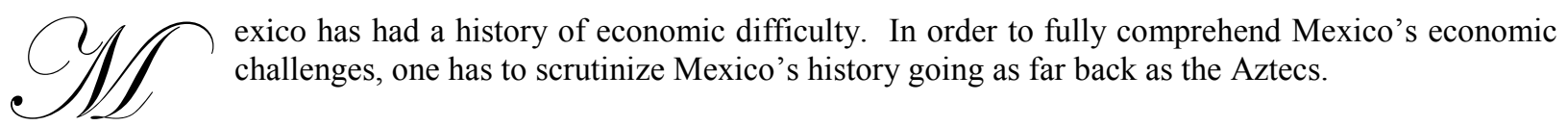

In the time of the Aztecs, their trade entirely focused on the success or failure of the cultivation of their crops. Mexico is located in the tropics with weather conditions similar to that of Florida where crop failures occasionally occurred due to the cycles of the weather. Because they did not understand the weather cycles, they blamed the failure of the crops on displeasing the gods. The Aztec' and Mayas' theological beliefs professed the idea that humans were created from corn. (Hall, Schwarf and Root, 2006) If the crops were bad, Aztecs would offer sacrifices to appease the "weather gods" to solve this problem. (Suchlicki, 1996)

In 1518 the Spanish initiated their exploration of Mexico. (www.carpenoctem.tv/military/cortes.html, retrieved on November 16, 2005). The Aztecs were experiencing crop failures during the time of the Spanish exploration of Mexico. (Suchlicki, 1996) The attempts in manipulating the weather were not working and therefore, they began political restructuring frequently via revolution. The Aztec political structure ruled on intimidation and political restructuring was often violent. The timing for an outsider to take over, like the Spanish, could not have been better.

In 1518, the Spanish military gave an ambitious Hernando Cortes permission for further exploration of Mexico. (www.carpenoctem.tv/military/cortes.html, retrieved on November 16, 2005) Cortes formed an alliance with the Aztec's enemy, the Tlaxcalan Indians. Cortes anticipated significant resistance in overthrowing the Aztec; therefore he manipulated his relationship with the Tlaxcalan's to gain their support in overthrowing the Aztecs. (Suchlicki, 1996)

Montezuma tried to appease the Spaniards but his peace efforts only excited Cortes. (Suchlicki, 1996) Legend has it, that Cortes asked Montezuma to fill an entire room full of gold. Montezuma filled the room with gold hoping to appease Cortes and end the violence. Conversely, when Montezuma did this, Cortes became impressed with the riches the Aztecs possessed, and only wanted more wealth which resulted in Cortes attacking the Aztecs. Montezuma and the Aztecs could not overcome the Spanish conquistadors with their horses and firearms, neither of 
which the Aztecs had seen before. (www.carpenoctem.tv/military/cortes.html, retrieved on November 16, 2005) In November 1519 Cortes conquered the Aztecs. He captured Montezuma and used him as his mouthpiece for the Aztecs. (Suchlicki, 1996) Montezuma was killed in battle trying to overthrow the Spanish after his capture. (www.carpenoctem.tv/military/cortes.html, retrieved on November 16, 2005)

Cuauhtémoc assumed leadership of the Aztecs after Montezuma's death. Cuauhtémoc executed Spanish prisoners in an attempt to exterminate the Spanish from the Aztec culture. Cuauhtémoc also killed fellow Indians who sympathized with the Spanish. Because of this, he did not have the strong support from his fellow Aztecs as Montezuma had. The Spanish eventually captured Cuauhtémoc, tortured him for many years and ultimately executed him. (Suchlicki, 1996) This established a permanent Spanish presence in Mexico.

\section{ETHNIC MAKE UP OF MEXICO}

Today there are three predominant races in Mexico, Spanish, Mestizos and Indians. The Spanish citizens are direct descendants of the Spanish conquistadors. Mexicans who are in this class live in the cities, are usually professionals, usually higher educated and generally more prosperous. (Suchlicki, 1996)

Two-thirds of the population of Mexico are Mestizos, part Indian (Aztec/Mayan) and Spanish. (Gianaris, 1998). Mexicans in this class balance between the two cultures, and are more likely to flee to the United States borders for employment. (Suchlicki, 1996)

The Indians citizens are direct descendants of the Mayans and Aztecs. Mexicans who fall in this class are typically poor and live in the southern rural areas. Indians compose most of the guerrilla armies in Mexico. (Suchlicki, 1996)

Today approximately sixty-percent of the population is comprised of Mestizos and Indians. Spanish is the official language of Mexico. Prior to the Spanish movement, there were over two hundred Indian dialects. (Gianaris, 1998) Many of these dialects became extinct, adding oppression on the remaining Indian and Mestizo population. With each change in government the Indians and Mestizos sunk further and further in poverty. Throughout Mexico's history, every political and economic change oppressed the Indian and Mestizo population.

The Spanish presence brought the Jesuit and Catholic movement. Since Aztec culture merged politics and religion together, therefore Mexico readily embraced the new Spanish-Catholic influence. However, the Jesuits established too much presence in Spain and Mexico. By the 1700's the Spanish crown feared the Jesuits' loyalties lied more with the Pope than with the Crown. Actually as the Jesuits gained a power and wealth, they began to operate independent from the Crown and the Vatican. However, the Jesuit's loyalties lay more within themselves. The Jesuit's presence was soon overthrown and they were forcibly removed from Spain and Mexico. The remaining native Aztec Indians and Mestizos were soon thrust further into poverty with the immediate disappearance of Jesuit influence. (Suchlicki, 1996)

The Crown's influence and forceful removal of the Jesuits were not welcomed by Mexico. In the 1800's, Mexico began to fight for their independence with the help of the Creoles. (Suchlicki, 1996) This would be the first of many Indian uprisings in Mexican history. After many failed attempts, Mexico finally broke free from Spain in 1824. The war delivered Mexico a great warrior and unscrupulous officer, Antonio Lopez de Santa Anna. (http://www.lsjunction.com/people/santanna.html, retrieved November 27, 2005) Santa Anna would grow to be quite prominent throughout Mexico and American History.

\section{BALANCING INDEPENDENCE AND ECONOMIC STABILITY}

The saying is To the victor goes the spoils, and Mexico's first president, Guadalupe Victoria won an empty treasury and devastated economy as a result of its lengthy conflict with Spain. The Mexican government has a long history of being unstable. For the next fifty years thirty different individuals would be president. With the exception of President Victoria, there would not have been a president who would have lasted more than two years 
without being overthrown or assassinated. (Suchlicki, 1996) From 1833 to 1855 Mexico had thirty-six changes in presidents. (http://www.pbs.org/weta/thewest/people/s z/santaanna.htm, retrieved August 20, 2006) This revolving door of presidents led to more economic instability. Each president inherited an even worse economy than the one before.

Antonio Lopez de Santa Anna led Mexico for the longest period, although it was intermittently. Santa Anna himself directly ruled eleven times. During Santa Anna's first term, his vice-president ran the country more than Santa Anna. When the vice-president unleashed aggressive reforms to the church, state and military, Santa Anna led a military coup d'état and seized the opportunity to re-establish himself as head of Mexico. (http://www.pbs.org/weta/thewest/people/s_z/santaanna.htm, retrieved August 20, 2006) Santa Anna ruled Mexico for 1833-1835, 1839, 1841-1842. He was overthrown for a brief period by Nicolas Bravo, but regained power 1843. He was overthrown again by Valentin Canalizo and regained power again briefly in 1844 before totally relinquishing power to Valentin Canalizo. (Suchlicki, 1996) Santa Anna believed in a centralized autocratic form of government and chose to reject Mexico's constitution and democracy during his rule. (http://www.pbs.org/weta/thewest/people/s z/santaanna.htm, retrieved August 20, 2006)

Santa Anna became an honored and popular leader due to his key role in the Texas/Mexican revolution. The United States was infected with delusions of grandeur in their belief of manifest destiny and believed they were god's chosen people to create a model society. (Cateora, 1971/2005) The United States tried to take the Texas territory from Mexico peacefully and in 1829 President Andrew Jackson offered Mexico five million dollars for its vast and under-populated land. (Suchlicki, 1996) This was a hefty price that could have greatly helped Mexico's economy; however Mexico turned down the proposal. Americans, fueled with desire, went to war with Mexico leading to the infamous 1836 Battle of the Alamo. The United States invaded Mexico several times before achieving success. The United States annexed the land, which now makes up Texas, New Mexico and Arizona. Mexico had a strong military, but continued to make poor political and economic decisions. The constant change in government resulted in being taken over by France for several years. In 1917 Mexico regained their independence and adopted their form of democracy and constitution. (Suchlicki, 1996)

\section{SELF-SUFFICIENT OR GLOBAL}

Mexico has continued to struggle to achieve economic stability. In 1934, under the Lazaro Cardenas' administration, Mexico isolated itself from the international economy. (Goddard, 1994) Mexican government closely controlled business establishing a legitimate business involved a lot of bureaucratic red tape. This led to many otherwise legal businesses to operate underground. (Aldonas Testimony, 2006) To promote this isolation, they protected their domestic business interests with high tariffs. (Goddard, 1994) This was a standard practice at the time in most countries to protect their own businesses and economic interests. Mexico further isolated itself by having a democratic government with an economy that resembled a Marxist economy. Marxists economic doctrine supports independent development but resists an international economy. While theoretically Marxism seems to promote a superior economy, this egocentric economy contributed to the Soviet Union's ruin and demise (Goddard, 1994) and Mexico remained a third world country for decades due to the Marxist economy. The businessmarketing arena makes it difficult, even impossible, to maintain a totally domestic market. It is crucial in today's world economy for businesses to compete globally to survive. (Goddard, 1994)

During the George H. Bush administration, the United States began to struggle to compete in the international market place as Mexico continued to struggle to gain their own political and economic stability. The United States' solution was to enlarge the marketplaces in the western hemisphere because Europe and Japan were beginning to dominate the international marketplace. (Goddard, 1994) In 1991 President George H. Bush began the Enterprise Americans Initiative (EAI). The foundations of EAI required the creation of hemispheric free trade and begin negotiations with Mexico, United States and Canada. (Goddard, 1994) The EAI was created to include all of the Americas. This was a sign that the United States was shifting from multilateralism and toward the World Trade Organization. (Gianaris, 1998) This aided to the birth of NAFTA. 
NAFTA was a bi-partisan accomplishment for the United States. It was negotiated under President George H. Bush and signed under President William Clinton's administrations. retrieved August 5, 2006) Politics aside, the (http://terr.benezet.org/phpnuke/modules.php?name=News\&file=article\&sid=562 goals of NAFTA remained the same:

1. Expand the success of the current free trade agreements between the United States and Canada.

2. Address and counter the threat of the success of the European Union by creating a North American Trade bloc.

3. Integrate the Mexican economy in the United States and Canada.

4. Cultivate growth in Mexico by employing capitalistic reforms, which can provide a force to bring Mexican workers out of destitution. (Nevaer, 2004)

President Salinas supported involvement with NAFTA. He realized Mexico would have to make changes to participate in EAI and negotiate for NAFTA. Salinas' growth strategy was:

1. Permanent stabilization of economy

2. Improve social conditions

3. Enlarge resources

4. Modernize economy (Goddard, 23, 1994)

Salinas realized they had to drastically change Mexico's policy to eliminate tremendous international debts. They needed to attract foreign capital to resume economic growth. Salinas removed restrictions on foreign direct investments to create an attractive macroeconomic environment to foreign investors. (Goddard, 1994) Foreign direct investments have become crucial in the global economy, but even more so in developing countries than developed countries. (Nunnenkamp, P., 2002)

Salinas was preparing Mexico for their great future with NAFTA. However, Mexico did not forget their love/hate relationship with the United States. Not all of Mexico supported NAFTA and President Salinas' plan. Throughout their history, every great change has oppressed the remaining native Aztec Indians and the Mestizos further and further into poverty. Mexico's goal in the war of independence with the Spanish was to demolish the classes. However, after the war the Indians and Mestizos sunk even lower into poverty. (Suchlicki, 1996) Not all of Mexico was willing to accept America's sudden interest and help in their well-being.

Mexico remembers:

1. America took one-half of their territory

2. America invaded Mexico several times

3. America has meddled into their affairs

4. America has exercised undue influence over their economy and government. (Suchlicki, 1996)

NAFTA was signed in January 1994. After the signing, there was a guerilla uprising in Chiapas, which resulted in several small bombings in Mexico City. The guerilla armies are primarily made up of native oppressed Indians. The hostilities continued through March 1994 when newly elected president, Luis Colosio, was assassinated before being appointed to office. Ernesto Zediollo replaced Luis Colosio. Zediollo tried to boost the economy and devalued the peso. In 1995 President Zediollo publicly blamed his predecessor, Salinas for the economic problems and Salinas' brother for Colosi's assassination. (Suchlicki, 1996) Although Salinas tried, he did not prepare Mexico for the competition that NAFTA delivered. (Smith \& Lindlad, 2003) Salinas set up a good policy, but due to lack of support was not able to follow through. (Suchlicki, 1996) Mexico began to experience similar economic difficulties as to what it experienced prior to NAFTA's signing (Aldonas Testimony, 2006). History began to repeat itself, again. Because NAFTA tied the economies of Mexico and the United States together, (Harmon, 2001) the United States had no choice but to give Mexico a $\$ 40$ billion bailout. (Smith \& Lindlad, 2003) The country recovered from this crisis faster because of Mexico's ties with the United States and NAFTA. (Aldonas Testimony, 2006) 
Mexico's problem was not only economic and political instability. Mexico's problem was a largely uneducated workforce. (Smith \& Lindlad, 2003) The only jobs Mexico could immediately support after the signing of NAFTA were blue-collar jobs. Salinas tried to improve Mexico's education system prior to the implementation of NAFTA. Some of these changes have lasted long past Salina's administration and through Vicente Fox's. One of Salina's goals was to equalize the education in the affluent and underprivileged areas of Mexico. Basic educational reforms began in spite of UNESCO's and World Banks recommendations to begin them after economic reforms. Advances have been observed in the effectiveness of fundamental education in the underprivileged areas, mainly because there was more room for improvement in these areas. However, there has not been any tangible proof of said improvement. (Ornelas, 2004) The numbers of high school graduates from before NAFTA has increased eight percent in the first ten years of NAFTA's inception, and college graduates have nearly doubled. (Smith \& Lindlad, 2003) Prior to NAFTA, Mexico dedicated 3.6\% of their GDP to public education in 1990. Post NAFTA, in 2002 they dedicated $5.3 \%$ to public education. This is comparable to the United States' investment of $5.7 \%$ and Canada's $5.2 \%$ in 2002. (Home Development Report, 2005) Based on international comparisons, Mexico still remains deficient in mathematics, sciences and languages. This is due to high school education graduating students who are not prepared, along with fifteen of the largest universities following an automatic passing throwback. (Ornelas, 2004)

Mexico still has a lot to accomplish in order to bring its standards to a more competitive plane in the world's economy. (Ornelas, 2004) One American business owner stated that if he opened a plant in Asia he would have all the workers he needed in one country, from blue collar to engineers and technicians. This is not possible in Mexico. (Smith \& Lindlad, 2003) This is one reason why America chooses to send jobs to China over Mexico. Another reason is economic. In 1998, the minimum wage in Mexico was $\$ 1.47$ /hour versus $\$ 0.59 /$ hour in China. Mexico's per capita income is ten times higher than that of China's. (Smith \& Lindlad, 2003) It was better for American businesses to move to the Far East to open businesses instead of investing in the country south of the boarder mainly because of these two concepts - higher educated workforce and average lower wage.

Against most predictions, NAFTA had very little effect on jobs for the United States and Mexico. Recent models show little if any net changes to the United States jobs due to NAFTA. The changes that did occur were increased in employment in the United States. (Aldonas Testimony, 2006) In 2002, exports from the United States to Mexico and Canada supported 2.9 million U.S. jobs. That is an increase of 900,000 jobs since NAFTA's implementation. (US Trade Report) Mexico managed to become a major manufacturer, producer and exporter of low cost electronics and an integral part of the United States' automotive industry. (Harmon, 2001) In 2003 most of the exports to Mexico were parts and components to be assembled into final products and imported back into the United States. Examples of products shipped to Mexico for assembly are: refrigerators, televisions, automobiles and computers. This has flourished under the NAFTA Agreement. Most of these are assembled in the Maquiladora export processing zones. Maquiladora plans increased from 2,114 in 1993 to 3,251 in 2003. (Scott, 2003)

In some cases, Mexican industries moved to the United States for economic reasons. For example, a Mexican copper producer moved their plant to Amarillo, Texas because electricity in Mexico was 8.5 cents per unit versus 4 cents in Texas. (Smith \& Lindlad, 2003)

\section{THE MOUNTIES SAVE THE DAY}

Mexico had placed itself in a difficult situation and NAFTA became a litmus test to see if Mexico was ready for a major move into the international marketing arena. NAFTA helped Mexico have a more stable democratic government. (Smith \& Lindlad, 2003) and it was clear that Mexico needed to become a global economy. However, nearly 10 years after NAFTA, Mexico was still struggling. A Mexican economist, Salvador Kalifa, stated once Mexico signed NAFTA, they were committed to globalization with no option of quitting. (Smith \& Lindlad, 2003) Mexico needed the assistance of NAFTA to stabilize itself and survive.

Canada needed blue-collar workers and went way south of the border. Thus Mexico's savior was Canada (Fox, 2002). Mexico and Canada had been cultivating an economic relationship since the 1960's. NAFTA only aided in building the relationship. (Nevaer, 2004) Magna, Canada's largest auto parts manufacturer has established 
chassis plants in Mexico. Dofasco, Magna's steel company, and the engineering company was building Dofasco's new plant, open up business in Mexico as well. (Fox, 2002) Canada also opened locomotive and subway plants in Mexico, giving them 2,000 new jobs. (Smith \& Lindlad, 2003) In 2002, Canada granted 13,000 temporary Mexican employees to come to Canada for education in the agriculture, meatpacking and tourism sectors of business. (Fox, 2002) While it appeared that American turned its back on Mexico, Canada was moving south to a welcoming Mexico.

Trade between Mexico and Canada is continuing to grow. Alberta and Manitoba established investment programs and trade offices in Mexico. Canadian investors have financed \$3.8 billion in Mexico between 1994 and 2001. (Fox, 2002)

Canada is further helping Mexico in regard to their political issues. Canada is advising the Mexican administration in regards to addressing problems with their economy, i.e. debt reduction and establishing a social security system. (Fox, 2002) Although trade and business between Mexico and Canada increased, Mexico needed assistance in providing immunization and health care programs. Trade generates wealth so the government can allocate funds to provide for these necessary programs. NAFTA forced Mexico to make reforms forcing the government to make allocations to keep up with the growing economy and growth. (Smith \& Lindlad, 2003) Canada is working with Mexico to assist in their growing pains. Canada is the third largest FDI in Mexico. Canada is promoting trade in Mexico and Mexico is Canada's leading exporter. (Fox, 2002) NAFTA has drawn the border between Mexico and Canada closer. Mexico has found a new ally in the world's economy. The alliance between Mexico and Canada could lead to a major challenge to America as the primary force in NAFTA. (Nevaer, 2004).

\section{NORTH MEXICO VERSUS SOUTH MEXICO}

Most of the successes in Mexico that have been attributed to NAFTA have occurred in the areas closest to the United States-Mexican boarder and central Mexico. United States auto manufacturers have invested billions of dollars into northern Mexico. (Hall, Schwartz, and Root, 2006) Magna Corporation, based in Aurora, Ontario, Canada established a satellite plant in central Mexico. (http://www.magna.com/magna/en/about/history/default.aspx, retrieved September 2, 2006)

While northern Mexico has prospered, southern Mexico has not had great improvements. Southern Mexico lacks highways and close ties to the United States. Southern Mexico is the agricultural area of Mexico. NAFTA has had harsh affects on Mexican farmers. The United States has flooded Mexico with corn as livestock feed and bulk corn. Mexico could purchase sacks of corn from the United States for a fraction of the price of corn from Mexican farmers. This has forced Mexican farmers to flee to more urbanized areas and to immigrate to the United States for employment. Newly elected President Felipe Calderon has recognized a need for improvement in Southern Mexico. (Hall, Schwartz and Root, 2006)

There are also great differences in the educational levels between Northern Mexico and Southern Mexico. Mexico has offered incentives to teach in remote and poorer areas and has made advances to equalize the educational levels between Northern and Southern Mexico. However there has not been a significant improvement between the rich and poor states. (Ornelas, 2004) Impact of NAFTA

Opinions vary on if NAFTA has been worth its ink or not. The supportive evidence on the subject varies as much as the opinions do. The American Farm Bureau Federation's economic analysis team states NAFTA has been a "winner" for all three countries involved. (Skorburg, 2002) This is not a statement you would expect from the American Farm Bureau. The three areas they felt had the most positive changes associated with NAFTA are: 1) Since NAFTA's commencement agriculture trade has doubled for all three countries. 2) Competitive market forces have a more domineering role in the determination of trade flows. 3) NAFTA instated regulations to alleviate potential trade frictions (Skorburg, 2002) 
United States-Mexican trade rose to $\$ 247.6$ billion by 2000 . (Woodhead, 2001) Trade among all counties involved in NAFTA more than doubled, from $\$ 302$ billion in 1993 to $\$ 652$ billion in 2003. (Aldonas Testimony, 2006) The trade surplus the United States had with Mexico in 1993 shifted to a large deficit reaching $\$ 24.2$ billion in 2000. United States exports to Mexico increased 168\% from 1993 to 2000. (Woodhead, 2001) United States exports to Mexico increased to $95.2 \%$ in 2002. This resulted in an $\$ 85$ billion United States net export deficit with Mexico and Canada in 2002. (Scott, 2003) Ironically, these deficits are bad for the United States, but they show a market growth for Mexico. This is explained further in Chart 1.

\section{Chart 1}

\begin{tabular}{|l|c|c|c|c|}
\hline \multicolumn{3}{|c|}{} & \multicolumn{2}{c|}{ Changes since 1993 } \\
\hline Changes in US-NAFTA Trade & $\mathbf{1 9 9 3}$ & $\mathbf{2 0 0 2}$ & Dollars & Percentage Change \\
\hline Mexico & & & & \\
\hline Domestic exports & 44 & 85 & 42 & $95.20 \%$ \\
\hline Imports & -45 & -134 & -88 & $195.30 \%$ \\
\hline Net exports & -2 & -48 & -47 & $3057.20 \%$ \\
\hline Source: EPI Briefing Paper: The High Price of 'Free' Trade, Nov. 2003 \\
\hline
\end{tabular}

All of this has resulted in economic growth and a better standard of living in Mexico. The Mexican economy grew three-percent a year during the first ten years of NAFTA. Production in Mexico increased fifty-five percent. This resulted in a twelve percent rise in the GDP. (Aldonas Testimony, 2006)

During the first seven years of NAFTA, Mexico has had large trade surplus with the United States. Mexico has a trade surplus with the United States in vehicles ( $\$ 17.3$ billion), automotive parts ( $\$ 6.7$ billion). (Woodhead, 2001) This surplus resulted in lost jobs for the United States, but increased jobs and revenue for Mexico. One peculiar way Mexico is receiving revenue is through its importing, assembling and exporting goods through the Maquiladora export processing zones. Parts are imported from the United States duty free. They assembled and are then re-exported to the United States with duties paid on the value that Mexico added. (Scott, 2003)

The increases in Mexico are somewhat a result in the increase in education. There has been a gradual rise in the literacy rates in Mexico, which aided in preparing them for the demands of NAFTA (Gianaris, 1998) Salinas believed in human capital theory. Before entering into NAFTA, Salinas prepared Mexico by launching educational reforms that would last beyond his presidency and his successors. (Ornelas, 2004) The numbers of high school graduates from before NAFTA has increased eight percent and college gradates have nearly doubled. (Smith \& Lindlad, 2003)

The north-south dilemma in Mexico continues to be a challenge for the Mexican government. NAFTA has had a negative impact on the southern region causing internal strife and turmoil. The vast majority of the direct positive effect of NAFTA lies along the US Mexican border with only indirect benefits in the south due to a rising overall economy. (Hall, Schwartz, and Root, 2006)

\section{SOLVING THE STRUGGLE WITHIN}

In today's economy, countries must move from a strictly domestic market to a more global environment. NAFTA thrust Mexico into the international marketing arena - ready or not. There is no turning back now and Mexico must continue to promote education in their workforce. (Suchlicki, 1996) NAFTA has made Mexico realize the importance of political and economic stability. However not all of the work lies on Mexico's back. The United States must keep in mind that all three economies of Mexico, Canada and the United States' economies are now tied together. The United States has helped Mexico financially in the past by giving aid to Mexico during the aforementioned peso crisis under Mexican President Zediollo. (Smith \& Lindlad, 2003) However Canada believes in the saying, Give a man a fish, feed him for a day. Teach a man to fish, feed him for a lifetime. Canada is advising 
Mexico on how to improve their workforce by investing in educating and moving businesses there. Canada is helping Mexico reduce their debt and establish a social security system. (Fox, 2002)

One area Mexico needs to drastically improve upon is widening their market base. Eighty-percent of United States-Mexican trade is intra-industry trade. (Woodhead, 2001) It is no surprise that Canada, the third member of NAFTA, has the third Largest FDI in Mexico. Mexico is Canada's leading export target. (Fox, 2002) Mexico needs to expand beyond the NAFTA countries to be able to stand-alone from the United States and Canada to rise from a third world to a developed nation and a contender in the international business arena.

The biggest challenge is Mexico's persistent north-south economic, socio-cultural divide. The 2006 presidential election polarized the country with the liberal party winning the agrarian south and the conservative party winning the capitalist north. (Hall, Schwartz and Root, 2006)

\section{ANALYSIS}

Historical, anthropologic division compressed of three genres of peoples, Spanish, Mestizos and Indian, and the corresponding geographic enclaves are Mexico's biggest challenge.

\section{LIMITATIONS OF THE STUDY}

The paper is an applied paper and focused on the history and the ethnic developmental aspects more so than the economic past. This paper was based entirely on public statistical data and secondary information. A much more in depth study of the economic forces and socio-political forces at work in the north and south distribution of the population would have added more structure and support for the findings.

\section{DIRECTION FOR FUTURE RESEARCH}

Empirical studies of anthropological and geographic underpinnings would yield information that could aid in the formation of applied corrected activities by the Mexican Government. An expanded look at variables such as the contribution of FDI, education, distribution of funds within Mexico, work migration, remote employee donation to home town, para-governmental groups in the south, and other variables would further illuminate the foundations of cohesive and polarizing forces.

\section{SIGNIFICANCE TO INDUSTRY}

Countries and companies therein can capitalize on a low cost provider of goods and services to further their marketing mix of low cost and multi-facetted differentiated goods and services. Likewise a growing middle class and more economically stable Mexico provide a market for international goods and services. Mexico promotes a future hot bed of entrepreneurial opportunity as the economy rises and the direct and indirect benefits foster growth.

\section{CONCLUSION}

The future of NAFTA and its positive affect on Mexico will continue to lift the Mexican economy, promulgate international trade outside of NAFTA and give Mexico the economic wealth to solve the economic plight of the southern region. Overcoming anthropological cultural dimensions due to a three tier sociological structure, Spanish, Mestizos and Indian, will prove to be the challenge. An emphasis on distribution of wealth across all of Mexico, increased widespread educational efforts and incubation of entrepreneurial enterprises in the south will give rise to a more homogenous and prosperous Mexico made possible by the commitment to NAFTA and increased international trade. 


\section{REFERENCES}

1. Aldonas, G.D. (n.d.) Testimony of Undersecretary of Commerce for International Trade: The Impact of NAFTA on the US Economy. http://www.mac.doc.gov/nafta/AldonasTestimony.pdf, retrieved June 19, 2006

2. Cateora, P. (2005). International Marketing (12th ed.) (J. Kroger. Biernat, Ed.). New York: McGrawHill/Irwin. (Original work published 1971)

3. $\quad$ Fox, C. (2002, September), What about Canada? Business Mexico (8), 26.

4. Gianaris, N. (1998). North American free trade agreement and the European Union. Westport, CT: Praeger.

5. Goddard, C. R. (1994) Confronting Globalization: Atencio Plasticos' Search for Strategic Alliance [International Business Case Studies] (R. T. Moran, D. O. Braaten, \& J. E. Walsh, Eds.). Houston, TX: Gulf Publishing Company.

6. Harmon, B. (2001, August 17). Latin America feels pinch of US slowdown. Kiplinger Finance \& Forecasts, 2.

7. http://terr.benezet.org/phpnuke/modules.php?name=News\&file=article\&sid=562, retrieved August 5, 2006

8. http://www.magna.com/magna/en/about/history/default.aspx, retrieved September 2, 2006

9. Mexico rejects renegotiation of NAFTA. (2004, April 16). Agra Europe, 1(2101), 7.

10. Nevaer, L. E. (2004). NAFTA'S second decade: Assessing opportunities in the Mexican and Canadian Markets (J. Calhoun, Ed.). Mason, OH: Thomson South-western.

11. New Perspectives on the West, http://www.pbs.org/weta/thewest/people/s z z/santaanna.htm, retrieved September 11, 2006

12. Nunnenkamp, P. Foreign Direct Investment in Developing Countries: What economists (don't) know and what policymakers should (not) do! , Monographs on Investment and Competition Policy 11. Centre for International Trade, Economics and Environment (CUTS), Jaipur, 2002

13. Ornelas, C. (2004). NAFTA and Mexican higher education. In S. Weintraub (Ed.), NAFTA's impact on north-america: the first decade (Vol. 26, No. 5, pp. 285-303). Washington, DC: Center for strategic and international studies.

14. Pisher, K., and Pisher, M., Seize the Night. www.carpenoctem.tv/military/cortes.html, retrieved on September 11, 2006

15. Skorburg, J. (2002). An economic analysis of NAFTA by commodity 1994-2000. Washington, DC: American farm bureau federation, economic analysis team.

16. Smith, G., \& Lindlad, G. (2003, December 22). Mexico: Was NAFTA worth it? Business Week (3863), 6672

17. Suchlicki, J. (1996). Mexico: From Montezuma to NAFTA, Chiapas, and beyond. Washington, D.C: Brassey's Inc. Smith, G., \& Lindlad, G. (2003, December 22).

18. Woodhead, G. (2001). NAFTA's seven-year itch (AFI-CIO, Public Policy Dept). Washington, DC. 
NOTES 